\title{
THE REVIVAL OF SACRED SITES IN THE URALS: THE LOCAL AND BEYOND
}

The Islamic revival in the Ural region does not only translate into an increase in mosques and institutions of religious education (madrasas), such as the newly built Rasulev madrasa, named after the well-known Sufi sheikh or ishan Zaynulla Rasulev (1833-1917), in the city of Troitsk. Sacred sites are also places where one can witness a renewed religious activity. Hence, in the same city of Troitsk, the grave of Rasulev attracts numerous pilgrims and Muslim officials with a steady increase in the number of visitors in recent years, as the cemetery guard tells us on a mild July day. The number of visitors was particularly high during the annual Rasulev readings, two weeks before our visit. Sacred sites in the Urals have become centres of encounters of different pilgrims and visitors, and also places where identities - religious, ethnic and national are (re)formed and strengthened.

\section{Nature and the Sacred}

On a mild summer day, we accompany a group of Bashkir Sufi disciples (murids) to a remote place deep in the mountains in central Bashkortostan. We leave our minibus at the beginning of a bumpy and muddy road and continue by foot. On the way, our companions are busy collecting plants, flowers and berries, reflecting upon their healing virtues, which are different for men and women. We converse with an older Bashkir man, with the adopted Arabic name of Abdulkarim, who vividly explains to us how Bashkirs have always lived close to nature. He talks about nature as a source of strength (sila) and energy for humans; city life deprives people of this energy. He claims that a pilgrimage (ziyarat) will replenish his or her energies for at least one month. Jesko Schmoller receives a plant from a little boy, who has found it near the road and from which the national Bashkir instrument, the kurai flute, is made. ${ }^{1}$ Two older women tell us the story of the kurai: Bashkir nomads heard a beautiful melody and wondered where it came from. They saw a plant with a bird on it, who was breathing into the hole and producing the melody. Seeing this, the Bashkirs started playing the flute. The connection to the Bashkir landscape is also present in the story of the national Ural Batyr epos, as told by a group of Sufi women in a circle to Lili Di Puppo. Ural Batyr encounters an old man who invites him to drink the 'living water' in order to gain eternal life. Ural Batyr refuses, saying that it is not he who should be eternal, but the earth, the world. The women narrate the story as one of sacrifice for his people. Ural Batyr pours the 'living water' onto the top of the Ieremel mountain, from which seven rivers start to flow. ${ }^{2}$

The connection between sacred sites in the Urals and the surrounding natural landscape appears to be strong: these sites are often found in nature, far away from city life. Two of the sites we visited, Narystau and Aushtau, have grave sites of Muslim saints near a healing spring. In Central Asia, which is geographically and culturally rather close the distance from Aushtau to the border with Kazakhstan amounts to only about 100 kilometres - the simplest version of a sacred site would at least consist of a tree, a water source and a tomb (Abramson and Karimov 2007: 321). The natural landscape, which contributes to a sacred geography, for example in the form of healing springs or mountains such as the Ieremel moutain, is seen by some of our interlocutors as intimately linked to Bashkir identity. In her new book on Rasulev, the Bashkir writer Lira Yakshibayeva talks at length about different natural sites and laments the ecological disasters that have marked the 20th century. ${ }^{3}$ While deeply con- 
nected to the Bashkir earth, understood as sacred, these sites are also open to all pilgrims and visitors and often characterised by a mix of religions.

\section{Springs and Saints}

The way to Narystau from Sterlitamak, with a local Russian taxi driver, is long and difficult as the place is not known by the majority of locals. Only a little closer to the place are people able to indicate the direction to us. We later learn that the sacred site of Narystau is new. Boards at the entrance to the water spring instruct visitors to dress appropriately and not be naked, as this is forbidden by sharia; one board also advises people not to wear swimming costumes. However, we see members of a Russian Orthodox family sitting around the water spring in their swimming gear. In the adjacent bathing house we learn that they also consider Narystau a holy place and especially value the water there, but that the Muslim associations do not matter much to them. After taking a bath, we enter a small mosque, whose imam tells us the story of the sahaba, the companions of the Prophet Muhammad who are buried up on the small hills. A few days earlier in Chishmy, the burial site of Huseyn Bek, who played a major role in the region's Islamisation in the 14th century, we heard a Tatar imam in a local mosque invite Muslims to join a pilgrimage to Bolgar, a site near Kazan, where sahaba are also believed to be buried. These two sites can thus be seen in parallel as sites where both a Tatar and a more pronounced Bashkir identity are formed. Some local Muslims appear to visit both places; however, the site of Narystau seems to elicit scepticism from certain Tatar Muslim officials. The Narystau site also reveals the transnational dimension of a local Bashkir conversion story, as the transnational Naqshbandi Haqqani Sufi order (tariqa) has supported the building of the site. ${ }^{4}$ During a gathering of murids, a spiritual leader in the tariqa declares that Salafi Muslims can literally not take roots in Bashkortostan, as the Bashkir earth does not accept them. The spiritual leader talks in Bashkir about a line- age that has been re-established, evoking the renewed presence of the Naqshbandi tariqa among Bashkirs and referring to Rasulev.

The spring at Aushtau only carries water during the month of May, which is the time of year when the greatest number of pilgrims gather at the place, even from far-away countries such as Israel and Mozambique, as our guide, a Bashkir-Kazakh man in his fifties we met in the village, tells us. The site reveals efforts to regulate pilgrimage practice in the form of signs and boards warning against the sin of idolatry. One board explains that the pilgrim needs to ask only the Almighty for help and also carries recommendations for the recitation of specific chapters (suwar) and verses (ayat) of the Quran. It says that the Almighty will only accept the pilgrim's prayers, out of respect for his beloved slave, the wali, if the pilgrim came with sincere and pure intentions. Another board instructs visitors not to tie ribbons to trees near the grave site, as it is forbidden in Islam and leads to sin. Ironically, this is exactly what pilgrims have been doing all around the grave at the top of the mountain. In neighbouring Central Asia, the religious authorities likewise prohibit the use of ribbons at sacred sites, while many people do not comply with these instructions (Abramson and Karimov 2007: 320). The presence of ribbons thus evokes a broader pilgrimage space, transcending the Russian-Kazakh border and establishing a connection with wider Central Asia. The same can be said for the Kazakh pilgrims who regularly visit the tomb of Rasulev in Troitsk. Here, one also finds discussions around correct pilgrimage practice. At the grave site, we notice the porous surface of the gravestone, from which, we are told, Kazakh pilgrims break off small chunks, crush and mix them with water and drink the resulting substance. When we talk with imams and mosque-goers in Troitsk, they express some concerns about pilgrimage rituals that do not conform to Islam, even if they celebrate local customs that can be integrated into the religion. While today the ribbons are attached to the branches of trees in the hope of being granted a favour, in the past, according 
to one imam, pieces of cloth were hung up for poor people, who could take them and turn them into items of clothing.

\section{Conclusion}

The observation of sacred sites helps approach the question of how a local Islam, inscribed into a particular territorial sacred geography, shows a capacity to create multiple connections, sometimes with far-away places in the Muslim world. The interconnection between the 'local' and the 'transnational' in these places helps problematise the conventional dichotomy, which one often encounters in the post-Soviet space between a local, 'ethnic', Islam and a universalist, 'foreign', Islam. The universalist and transnational dimension of Islam is often associated with Salafi interpretations of the religion. The observation of sacred sites in the Urals region reveals that pilgrimage practices that can be associated with the notion of 'traditional Islam', in the sense of a 'popular' Islam, likewise have a transnational dimension. Pilgrimages reveal a deep spiritual attachment to nature and to the Bashkir sacred earth, as well as attract flows of international visitors, thus connecting these sites to a broader Muslim space. Furthermore, the presence of the Naqshbandi Haqqani brotherhood also shows how transnational connections can contribute to the revival of Bashkir sacred geography and a local identity. Those pilgrimage practices, such as the tying of ribbons, which are seen as not conforming to Islamic rules, also evoke a broader pilgrimage space uniting Russia with neighbouring Central Asia. Finally, the boards near pilgrimage sites show efforts from above to regulate pilgrimage behaviour by making it conform to Islamic precepts, producing a local Islam grounded not only in the sacred soil but also in the universal foundations of Islam.

$$
\begin{array}{r}
\text { Lili Di Puppo } \\
\text { (HSE University) } \\
\text { Jesko Schmoller } \\
\text { (European University St. Petersburg/Perm } \\
\text { State University) }
\end{array}
$$

\section{Notes}

1 The plant from which the kurai flute is made is an Apiaceae or umbelliferous plant.

2 There are variations of this epos. We are told that Ural Batyr is considered a Muslim prophet by mountain Bashkirs; he is incorporated into the Islamic religion.

3 The Russian-language version of the book is titled Zaynulla-ishan. Chast' 1: Na puti $k$ istine.

4 Other brotherhoods are present in the VolgaUral area today, such as the Naqshbandi-Mujaddidi order, which was historically the most influential in the region, together with the NaqshbandiKhalidi order.

\section{References}

Abramson, David and Elyor Karimov. 2007. Sacred Sites, Profane Ideologies: Religious Pilgrimage and the Uzbek State. - Everyday Life in Central Asia. Past and Present, edited by Jeff Sahadeo and Russell Zanca. Bloomington, IN: Indiana University Press, 319-338.

Yakshibayeva, Lira. 2016. Zaynulla-ishan. Chast' 1: Na puti $k$ istine. Ufa: Kitap. [Якшибаева, Аира. 2016. Зайнулла-ишан. Часть 1: На пути к истине. Уфа: Китап.] 